Prosperity with growth: Economic growth, climate change and environmental limits

Cameron Hepburn and Alex Bowen

October 2012

Centre for Climate Change Economics and Policy Working Paper No. 109

Grantham Research Institute on Climate Change and the Environment Working Paper No. 93 
The Centre for Climate Change Economics and Policy (CCCEP) was established by the University of Leeds and the London School of Economics and Political Science in 2008 to advance public and private action on climate change through innovative, rigorous research. The Centre is funded by the UK Economic and Social Research Council and has five inter-linked research programmes:

1. Developing climate science and economics

2. Climate change governance for a new global deal

3. Adaptation to climate change and human development

4. Governments, markets and climate change mitigation

5. The Munich Re Programme - Evaluating the economics of climate risks and opportunities in the insurance sector

More information about the Centre for Climate Change Economics and Policy can be found at: http://www.cccep.ac.uk.

The Grantham Research Institute on Climate Change and the Environment was established by the London School of Economics and Political Science in 2008 to bring together international expertise on economics, finance, geography, the environment, international development and political economy to create a worldleading centre for policy-relevant research and training in climate change and the environment. The Institute is funded by the Grantham Foundation for the Protection of the Environment, and has five research programmes:

1. Global response strategies

2. Green growth

3. Practical aspects of climate policy

4. Adaptation and development

5. Resource security

More information about the Grantham Research Institute on Climate Change and the Environment can be found at: http://www.Ise.ac.uk/grantham.

This working paper is intended to stimulate discussion within the research community and among users of research, and its content may have been submitted for publication in academic journals. It has been reviewed by at least one internal referee before publication. The views expressed in this paper represent those of the author(s) and do not necessarily represent those of the host institutions or funders. 


\title{
Prosperity with growth: Economic growth, climate change and environmental limits
}

\author{
Cameron Hepburn and Alex Bowen ${ }^{1}$ \\ Grantham Research Institute on Climate Change and the Environment, \\ London School of Economics
}

Forthcoming as Hepburn, C. and Bowen, A. (2013), 'Prosperity with growth: Economic growth, climate change and environmental limits' in Fouquet, R. (ed.), Handbook of Energy and Climate Change, Edward Elgar.

$26^{\text {th }}$ October 2012

\begin{abstract}
Debate about the relationship between environmental limits and economic growth has been taking place for several decades. These arguments have re-emerged with greater intensity following advances in the understanding of the economics of climate change, increases in resource and oil prices and the re-emergence of the discussion about "peak oil". The economic pessimism created by the great recession of 2008-2012 has also put the spotlight back on the prospects for economic growth. This chapter provides a conceptual and synthetic analysis of the relationship between economic growth and environmental limits, including those imposed by climate change. It explores two related questions. Will environmental limits, including limits on the climate system, slow or even halt economic growth? If not, how will the nature of economic growth have to alter? It is concluded that continued economic growth is feasible and desirable, although not without significant changes in its characteristics. These changes need to involve ultimately the reduction of the rate of material output, with continued growth in value being generated by expansion in the 'intellectual economy'.
\end{abstract}

Keywords: economic growth, environmental policy, climate change, environmental Kuznets' curve, green growth, peak oil, green growth

JEL Numbers: E52, E61, Q43, Q48.

Email for correspondence: c.j.hepburn@1se.ac.uk

\footnotetext{
${ }^{1}$ The authors are grateful to Simon Baptist, Sam Fankhauser, Mattia Romani, Hyunjin Kim, and Dimitri Zenghelis for comments on this chapter and to Gavin Cameron, Dieter Helm, Ben Irons and Kevin Roberts for helpful suggestions and comments on a much earlier version of this chapter. Particular thanks are owed to Katerina Kimmorley and especially to Jonathan Colmer for their able and timely research assistance.
} 


\title{
1. Introduction
}

\begin{abstract}
"Saving the environment will certainly check production growth and probably lead to lower levels of national income. This outcome can hardly surprise. Many have known for a long time that population growth and rising production and consumption cannot be sustained forever in a finite world." 2
\end{abstract}

Debate has raged among and between economists, environmentalists and others about whether increases in production and consumption can be sustained forever, or whether we are eventually destined for a 'stationary state' of income, labour and capital. This debate, at times, has been remarkably heated and ad hominem. ${ }^{3}$

Perspectives on the extent to which environmental and resource constraints will limit economic growth might be grouped into three categories. The first view is that environmental factors pose no limitation to economic growth. For instance, Lomborg (2001, Chapter 12) claimed that resources are becoming more abundant. Simon (1981) famously asserted that there is no real limit to our capacity to keep growing, and made bets to prove it. Simon (1980) argues that the term 'finite' is 'not only inappropriate but is downright misleading in the context of natural resources'. 4 Until a decade ago, there appeared to be empirical support for the view that commodities were becoming more economically abundant (Johnson, 2000), given the long-term trend of declining commodity prices over the $20^{\text {th }}$ century (Dobbs, Oppenheim and Thompson, 2011). Such views are also in accordance with the central result of most standard neoclassical and endogenous growth models with labour, capital and human capital as the factors of production: provided technological progress continues, economic growth can be sustained indefinitely. And economic growth may generate technological progress, a view stretching back to Adam Smith's argument that the division of labour is limited by the extent of the market (Smith, 1776). Economic growth enlarges markets and permits greater specialisation and variety; increasing returns to scale stimulate economic growth (Young, 1928).

The second view is that environmental limitations will at least exert a 'drag' on economic growth. This environmental drag is caused by natural resource limitations and the various negative effects of pollution on productivity and human well-being. Nordhaus (1992) and Bruvoll et al. (1999) attempted to estimate the historical extent of the environmental drag and make tentative forecasts for the future. While these estimates are admittedly still relatively crude, the concept of the environmental 'drag' on economic growth has entered mainstream macroeconomics and is presented in standard graduate macroeconomics textbooks, such as Romer (2006).

\footnotetext{
${ }^{2}$ Tinbergen and Hueting (1992, p.56).

${ }^{3}$ See, in particular, the acerbic remarks of both Daly (1997) and Solow (1997).

${ }^{4}$ Within the specific context of energy and fossil fuels, Helm (2011) presents the opinion that the world is awash with fossil fuels. The contrary view, exemplified by Campbell and Laherrère (1998), is the 'peak oil' hypothesis that supply will flatten as demand increases, leading to higher oil prices. For a more recent expression of this view, see Sorrell et. al. (2010) and King and Murray (2012).
} 
The third view, reflected by the opening quote from Tinbergen and Hueting (1992), is that environmental limitations are significant enough to prevent sustained growth in consumption and production. This perspective has its origins in the writings of classical economists, such as Malthus (1798), who argued that living standards would ultimately be driven to a bare subsistence level, and Mill (1848), who argued that the economy would eventually reach a stationary state. ${ }^{5}$ Notable proponents of this viewpoint in the 20th century have included John Maynard Keynes, ${ }^{6}$ Sir John Hicks ${ }^{7}$ and Nicholas Georgescu-Roegen. ${ }^{8}$ Ironically, this viewpoint gradually became fiercely anti-establishment. It has seen a revival in recent years with popular books such as "“Prosperity without Growth"” (Jackson, 2009).

Some economists concede that the environmental impacts of growth may harm wellbeing but assert that environmental limitations need not concern us in the long run. Ultimately, enough economic growth, through the associated technological progress and shifts in preferences, will cure environmental degradation and hence remove any constraints on growth. Beckerman (1992, p 482) expresses the first leg of this argument with his usual clarity:

\section{Furthermore there is clear evidence that, although economic growth usually leads to environmental degradation in the early stages of the process, in the end the best - and probably the only - way to attain a decent environment in most countries is to become rich.}

This inverted U-shape relationship between environmental quality and per capita income is usually labelled the environmental Kuznets curve (EKC), drawing on an analogy with the observations of Kuznets (1955) on the relationship of income inequality to changes in per capita income. If studies were to provide convincing support for an EKC curve across a wide range of pollutants, including carbon dioxide, then we would be tempted to draw the conclusion that economic growth can be sustained indefinitely, as long as the vast majority of countries can graduate to high enough income levels.

However, careful thinking is required. The EKC literature seeks to answer the question of whether economic growth will ultimately lead to specific environmental improvements. This is a related but different question to whether environmental constraints in general will limit economic growth. Even if EKCs have wide applicability and economic growth is shown to benefit the environment in some respects, it is possible that environmental limitations will nevertheless slow growth, perhaps even to the point that we reach a stationary state. In the current economic context, with widespread pessimism about the economic outlook and anaemic growth at best in most major OECD countries, an eventual stationary state is now easier for some commentators to contemplate.

\footnotetext{
${ }^{5}$ Mill (1848) further implied that if we did not deliberately guide the economy towards such a stationary state, an environmental collapse would result.

${ }^{6}$ See, for example, 'Economic Possibilities for Our Grandchildren' in Keynes (1930).

${ }^{7}$ Hicks (1983, p 68) thought that once population is controlled, the 'Stationary State is no longer a horror. It becomes an objective at which to aim.'

${ }^{8}$ Georgescu-Roegen was a Distinguished Fellow of the American Economic Association and, according to Paul Samuelson, a 'scholar's scholar, an economist's economist'. See the preface to Georgescu-Roegen (1966).
} 
This chapter considers the three viewpoints and isolates the arguments that underpin each view. We draw a distinction between material economic activity (where the laws of thermodynamics and the limits to substitutability in production and consumption may eventually impose significant economic constraints) and intellectual activity. We observe that it is theoretically feasible for sustained increases in utility to result from increases in the level of intellectual development, even if the material economy ultimately attains a stationary state.

The chapter proceeds as follows. Section 2 presents the key concepts and examines the three views on the severity of environmental limitations to economic growth. It also reviews some empirical estimates of 'environmental drag' and discusses the relevance of the literature on the EKC. In section 3, we attempt to unify the competing perspectives, and argue that even in a materially stationary state, indefinite growth in well-being is possible because of progress in the intellectual economy. We also directly consider the notion of 'prosperity without growth' and the claim that stopping economic growth is necessary for resolving a problem such as climate change. Section 4 concludes.

\section{Conceptual clarifications}

Research into the relationship between economic growth and the environment is often focused on one of two distinct but related questions. First, do environmental constraints limit economic growth? Second, does economic growth improve environmental quality? We consider both questions in turn in this section. Before doing that, however, it is important to define what is meant by 'economic growth'

\subsection{Economic growth}

A growth rate is merely the (proportional) rate of change of a variable. References to 'economic growth' tend to refer to the rate of change in output, or, more specifically, in real gross domestic product (GDP). GDP is a measure of the market value of all final goods and services produced in the economy for a given year, adjusted to remove the impact of changes in the general price level. In this sense, economic growth reflects increases in the value of output as assessed by participants in the markets for goods and services. GDP does not measure increases in physical mass moving through the economic system. This is important, because although there are, ultimately, physical limitations on the material throughput of the economy, it is conceptually possible for growth in the value of goods and services to grow without bound.

A positive (negative) GDP growth rate implies that the market economy is expanding (contracting). An expansion in average GDP per head is very likely to be associated with an increase in average consumption per head, increasing that measure of material well-being. It also appears to be very helpful in contributing to reductions in the incidence of poverty (Kanbur, 2001; Collier, 2007). Faster growth after a period of slowdown can reduce unemployment and increase perceived investment opportunities, stimulating 'animal spirits'. Sharp slowdowns, as recently experienced in many OECD countries, usually lead to increases in unemployment, crime, mental illness and severe reductions in welfare. 
Friedman (2005) also argues that economic growth provides broader welfare benefits, in that it fosters 'moral societies' characterized by social and political liberalization, manifested in increased opportunity, tolerance, economic and social mobility, fairness and democracy. Furthermore, he asserts that economic growth is partly responsible for some of the great periods of technological and intellectual advance, particularly the Enlightenment. In short, irrespective of these wider considerations, it is evident that economic growth is important for welfare, especially in poorer countries, and that recessions and the absence of per capita growth (at least under existing economic and social arrangements) are damaging.

\subsection{Environmental limitations on economic growth}

Conceptually, perspectives of the environmental limitations on economic growth can be divided into the three categories set out in the introduction. The first perspective is the most optimistic - infinite economic growth is possible driven by technological progress and human ingenuity (section 2.2.1). The second perspective is that growth will continue but environmental limits will exert a 'drag' (section 2.2.2). Finally, the third position is that environmental limitations will, or at least might, eventually bring growth to a halt (section 2.2.3). We consider each perspective in turn.

\subsubsection{Sustained growth: neoclassical and endogenous growth models}

Most neoclassical and new-growth theory does not explicitly model environmental limitations, and hence never-ending growth is often possible. Solow (1956) showed that capital accumulation alone cannot support sustained growth, because of diminishing returns. However, the incorporation of (exogenous) technological progress allows indefinite economic growth. Extensions of the neoclassical model to include natural resources (e.g. Stiglitz, 1974) or pollution (e.g. Stokey, 1998) still conclude that unbounded growth can be supported by exogenous technological progress. The new breeds of endogenous growth models ${ }^{9}$ also generally give rise to limitless increases in economic output ${ }^{10}$ resulting from constant (or increasing) returns to ideas overcoming diminishing returns to capital. ${ }^{11}$ Again, many of these models abstract from environmental limitations and hence conclude that infinite growth is a possible, and indeed likely, outcome. Sustained growth is even found as an outcome in some models that include environmental limitations. Aghion and Howitt (1998, Chapter 5) and Grimaud (1999) show that growth is sustainable provided that the elasticity of intertemporal substitution is less than unity. Michel and Rotillon (1995) find unlimited growth when the marginal utility of consumption rises with pollution.

Standard neoclassical models prompted fierce criticism by authors such as GeorgescuRoegen (1975) and Daly (1997). Stiglitz (1997) replies that this criticism stems from a failure to understand the role of analytical models. He states, "We write down models as if they extend out to infinity, but no one takes these limits seriously - for one thing, an exponential increase in population presents almost unimaginable problem of congestion on our limited planet." 12 The danger is that, without adequate and very

\footnotetext{
${ }^{9}$ Prominent examples include Romer (1986), Romer (1990), Grossman and Helpman (1991) and Aghion and Howitt (1992).

${ }^{10}$ Limitless in the sense of output increasing without limit (not in the sense of there being no constraint on annual growth rates).

${ }^{11}$ General reviews of the early endogenous growth literature can be found in Grossman and Helpman (1994), Romer (1994) and Solow (1994).

${ }^{12}$ Solow (1997) similarly felt the need to explain to Daly the purpose of theoretical models.
} 
obvious caveats, conclusions of analytical models are taken seriously. Opschoor (1997) states bluntly of Stiglitz: "Well, he had me fooled, for one". Furthermore, Simon (1981) argues seriously (and capably) that "there is no meaningful physical limit - even the commonly mentioned weight of the earth — to our capacity to keep growing forever." Others, however, such as Clark (1997), claim never to have been misled: "The argument...has always struck me as an exercise in inanity, at least when carried to the limit of supporting the possibility of perpetual economic growth".

In any event, the odds of humanity surviving the implosion of our Sun in several billion years, let along thriving and continuing to grow out 'to infinity' would appear to be vanishingly small, irrespective of whether models such as that of Stiglitz (1997) are to be taken literally or not. The notion that we might enjoy unlimited economic expansion forever, without some kind of 'environmental drag', serves as a helpful conceptual benchmark. In practice, however, ignoring the environmental drag, however, is increasingly implausible as 'planetary boundaries' are exceeded (Rockström et. al., 2009). And environmental and resource pressures seem only likely to increase as the human population swells from 7 billion to 9-10 billion and, critically, as the number of middle class consumers grows from 1 billion to 4 billion people (Kharas, 2010). The question is: will that drag at some point reduce the growth rate to zero? Is it appropriate to invoke an 'environmental Laffer curve' by describing a future state where environmental degradation and resource consumption would clearly prevent future growth and then argue that there must be a prior turning point at which attempts to grow faster become self-defeating?

\subsubsection{Environmental drag}

The concept of an 'environmental drag' appears to have been introduced by Nordhaus (1992), in the course of engaging with Meadows et al. (1992). ${ }^{13}$ Nordhaus (1992) defines the environmental drag as 'true national income" ${ }^{14}$ growth when resources are 'superabundant (but not free)' and there is no pollution, minus actual 'true national income' growth, with scarce resources and pollution. The concept of an environmental drag on growth is now firmly within mainstream economics, as attested by its presentation in Romer (2006, Chapter 1), a standard graduate macroeconomic text.

Despite the usefulness of the concept of the environmental drag, few theoretical papers to date have explicitly provided analytical expressions for it. Nevertheless, it would be straightforward to derive the environmental drag for the models of Bovenberg and Smulders (1995), Byrne (1997), Stokey (1998), Aghion and Howitt (1998) and Grimaud (1999).

Empirically, the environmental drag can be divided into two components. The first component is the constraint on production due to the earth's limited natural resources. This has been of concern to economists for some time. Indeed, in deriving the rate of optimal extraction of a resource, Hotelling (1931, p.137) observed:

\footnotetext{
${ }^{13}$ No reference to the concept was found in the literature prior to 1992, and Nordhaus (1992) provides no citation when defining the term. Weitzman (1994) introduces a different 'environmental drag' concept, which represents the cost of environmental regulation, without reference to Nordhaus (1992). ${ }^{14}$ This includes appropriately measured consumption, plus the value of net accumulations or decumulations of all 'capital', including physical, human, technical, research and environmental capital.
} 
Contemplation of the world's disappearing supplies of minerals, forests, and other exhaustible assets has led to demands for regulation of their exploitation. The feeling that these products are now too cheap for the good of future generations, that they are being selfishly exploited at too rapid a rate, and that in consequence of their excessive cheapness they are being produced and consumed wastefully has given rise to the conservation movement.

Before Hotelling, Jevons (1865) was concerned with the effect of depletion of natural resources, warning of dire consequences for British industry upon the inevitable exhaustion of coal stocks. However, both Jevons and Hotelling appear to have underestimated human inventiveness and adaptability - new reserves have been discovered and substitutes have been developed for scarce resources. Indeed, there have been plenty of counter-examples to the assumption that no factor substitution is possible, a few of which are noted in Nordhaus (1973).

Nordhaus (1992) estimates the drag on growth from scarce resources, comparing a 'limited' case with a case where resources are counterfactually 'unlimited'. He finds the largest growth drag to be from limited energy supplies, amounting to only 15.5 basis points per year ( 0.155 per cent per year). The drag on growth from limited copper supplies was found to be 1 basis point per year, and by extension, 2 basis points for all nonfuel minerals. While these estimates are extremely crude, he proffers them because "it is hardly interesting to say we don't know". These estimates are shown in Figure 1, under the category of non-renewable resources.

\begin{tabular}{lcc}
\hline Source of Drag & $\begin{array}{c}\text { Impact on world growth rate } \\
\mathbf{1 9 8 0 - 2 0 5 0} \\
\text { (basis points per year) }\end{array}$ & $\begin{array}{c}\text { Impact on world output in 2050 } \\
\text { (percentage reduction) }\end{array}$ \\
Non-renewable resources & 15.5 & 10.3 \\
Energy fuels & 2.9 & 2.0 \\
$\quad$ Nonfuel energy & 0.0 & 0.0 \\
$\quad$ Entropy & & \\
Pollution & 2.9 & 2.0 \\
$\quad$ Greenhouse warming & 4.4 & 3.0 \\
$\quad$ Local pollutants & 5.2 & 3.6 \\
Land drag & $\mathbf{3 0 . 9}$ & $\mathbf{1 9 . 4}$ \\
Total &
\end{tabular}

Figure 1: Estimates of environmental drag by Nordhaus (1992)

A component of the non-renewable resources drag is retardation due to the second law of thermodynamics. This states that all physical processes (including transformation of materials or energy) must increase total entropy, a measure of thermodynamic 
disorder. ${ }^{15}$ One of the first expositions of the relationship between entropy and economic processes was an introductory essay by Georgescu-Roegen (1966). Paul Samuelson was impressed, writing in the preface: "I defy any informed economist to remain complacent after meditating over this essay". The entropy analysis was extended in Georgescu-Roegen (1971), where the enormous size of the flows of solar 'negentropy income' (free energy) is noted. ${ }^{16}$ In contrast, Nordhaus (1992) relies on these negentropy flows to support the estimate shown in Figure 1, concluding that, "as long as the sun shines brightly on our fair planet, the appropriate estimate for the drag from increasing entropy is zero". ${ }^{17}$

The second component is the drag from pollution. This is increasingly of concern to policy-makers. Nordhaus (1992) provides a rough estimate of the drag on world income growth from the greenhouse effect. His focus is on growth as traditionally measured by changes in the market value of output. Assuming a doubling of $\mathrm{CO}_{2}$ concentrations by $2050,{ }^{18}$ he estimates that the cost of the greenhouse effect would be between 0 and 2 per cent of world income, while policies to prevent it would use between 1 and 5 per cent of income. He takes 2 per cent as a compromise figure. Since Stern (2006) and the IPCC (2007), however, Nordhaus has updated these damage estimates to between $1.2-1.7 \%$ of global output. ${ }^{19}$ Stern (2006) estimates the corresponding numbers, in terms of the welfare-equivalent, balanced-growthequivalent reduction to be between 5 and 20 per cent. Finally, based upon data from the US EPA, Nordhaus (1992) estimates the annual cost of pollution control to be 3 per cent of total output. ${ }^{20}$ Based upon the estimates collected in Figure 1, Nordhaus (1992) concludes, subject to reservations about the tentative nature of his work, that "an efficiently managed economy need not fear shipwreck on the reefs of resource exhaustion or environmental collapse".

Nordhaus's estimates are now 20 years old and, as with the greenhouse warming estimates, it would seem more likely that drag estimates have increased rather than declined since 1992. Somewhat more recently, Bruvoll et al. (1999) evaluated the size of the environmental drag from seven air pollutants in a computable general equilibrium model of the Norwegian economy. The drag is calculated by examining three effects of these pollutants. First, the model assesses the impact of pollutants such as $\mathrm{SO}_{2}, \mathrm{NO}_{x}, \mathrm{CO}$ and PM10 on labour supply and productivity losses due to trafficrelated externalities and respiratory problems. Second, the corrosion impacts of $\mathrm{SO}_{2}$

\footnotetext{
${ }^{15}$ We note that natural scientists would advise us not to employ the term 'disorder' in this context. The precise, statistical definition of 'order' does not equate with the common, intuitive notion, except when applied to ideal gases and dilute solutions: see Sollner (1997).

${ }^{16}$ In particular, Georgescu-Roegen (1971) states that, "as surprising as it may seem, the entire stock of natural resources is not worth more than a few days of sunlight!"

${ }^{17}$ This conclusion is supported by the arguments of Young (1991), but disputed by Daly (1992) and Townsend (1992).

${ }^{18}$ This is consistent with the high projection by the Intergovernmental Panel on Climate Change (1990).

${ }^{19}$ There is a continuing and lively debate about whether these estimates adequately reflect climatechange risks, attitudes to risk, appropriate social discount rates and non-market costs of climate-change impacts.

${ }^{20}$ By way of comparison, Adkins et al. (2010) estimate the increase in cost of pollution control following a hypothetical carbon tax of $\$ 15 \mathrm{t} / \mathrm{CO}_{2}$. They find that foremost manufacturing industries, costs are estimated to increase by less than 2 per cent whilst for other industries, cost increases are larger. For example, refining LPG costs are estimated to rise the most (22.4 per cent), followed by other refining ( 9.8 per cent) and cement ( 5.7 per cent).
} 
on equipment, in addition to the damage to roads from traffic, are evaluated. Third, the direct effect of air pollutants on consumer utility is estimated. The authors calculate that the environmental drag on welfare growth is 23 basis points annually, and the drag on conventional economic growth is 10 basis points. This is more than twice the 4.4 basis point estimate by Nordhaus (1992). Given that Bruvoll et al. (1999) considered only three negative effects of seven air pollutants, the total drag on growth from pollution would be expected to be significantly larger.

These limited investigations suggest that the environmental drag on growth may be significant, and may have increased over the last couple of decades. Also, it may be larger if a more comprehensive measure of output than traditional GDP is used and if account is taken of the depreciation of all forms of capital. The World Bank has attempted to estimate countries' net saving rates, adjusted for major environmental damages and resource depletion (World Bank, 2006). It suggests that these factors significantly reduce net saving more broadly measured. Energy depletion, for example, is estimated to make annual true global net saving about 3.3 percentage points of gross national income lower than the traditional measure of saving; particulate emissions have an impact of 0.7 percentage points (World Bank, 2011). However, as a fraction of economic activity, these percentages are still rather small. The question that flows is whether these environmental limitations will eventually become large enough to the extent that we are ultimately destined to wind down to a stationary state.

\subsubsection{A 'stationary state'?}

Some endogenous growth models that consider environmental externalities generate an eventual stationary state. For instance, in an 'AK model' with pollution as a consumption externality, Michel and Rotillon (1995) show a stationary state to be optimal where the marginal utility of consumption falls or remains constant with pollution. Withagen (1995) similarly proves that the presence of a stock pollutant can change the optimal path from balanced growth to a stationary state. Stokey (1998) finds that sustained growth is not optimal. ${ }^{21}$

Whether a stationary state is likely or desirable obviously relates to the notion of sustainability. One definition, 'weak sustainability' requires that for economic growth to be considered sustainable, the total aggregate stock of capital, both physical and natural, should not decline over time. In other words, even if there is an environmental drag created by pollution and resource exploitation, or more broadly the reduction of natural capital, economic growth may still be sustainable provided that the level of physical (and other) capital increases at least as quickly as natural capital is depleted. This appears to be the concept motivating the World Bank's estimates of adjusted net saving rates. Heal (2011) discusses further the importance of measuring and assessing sustainability. Neumayer (2003) emphasizes the implications of weak sustainability, noting that, "According to weak sustainability, it does not matter whether the current generation uses up non-renewable resources or dumps $\mathrm{CO}_{2}$ in the atmosphere as long as enough machineries, roads and ports are built in compensation." In other words, if natural capital is perfectly substitutable with manmade capital, then welfare can be preserved provided aggregate capital stocks are not

\footnotetext{
${ }^{21}$ In Stokey's model, pollution is an input to production; hence as capital grows the real rate of return can only increase if pollution grows proportionally. Utility is assumed to be concave in consumption and convex in pollution, so such a path is sub-optimal.
} 
decreasing. Weak sustainability may thus be formalized through the concept of Hartwick-Solow sustainability, in which the total sum of all changes in capital stocks must be zero.

In contrast, 'strong sustainability' is largely understood to require the preservation of natural capital (or at least some minimum quantity), irrespective of its substitutability (or otherwise) for other forms of capital, although various definitions of strong sustainability have been advanced (Neumayer, 2003). If preservation of human welfare requires the preservation of aggregate stocks of natural capital (or indeed stocks of specific environmental capital, such as an atmosphere conducive to human life), then it may be that no increase in manufactured capital can compensate for reductions in natural capital. This does not necessarily condemn us to a stationary state - provided that natural capital stocks are protected, the rest of the economy might be able to continue growing - but strong limitations in the substitutability among capital stocks would seem to make a stationary state more likely. We return to reviewing the potential to preserve natural capital stocks while growing in section 3, on decoupling, following an analysis of the related question of the impact of economic growth on the environment.

\subsection{The impact of economic growth on the environment}

It is possible to argue that the drag of environmental degradation on growth will diminish in importance because economic growth itself will lead to a better environment. Like many environmental issues, views on the effect of economic growth on the environment are unnecessarily polarised. Green organisations stress, correctly, that economic growth increases waste and pollution. The 1972 Club of Rome report into the 'Limits to growth' modelled a business-as-usual global system collapse by the middle of the $21^{\text {st }}$ century due to finite resources (Meadows et al., 1972). Similar arguments were advanced by Schumacher (1973) and Mishan (1967). Turner (2008) argues that the past 30 years has provided evidence broadly in line with their base case. Others argue, again correctly, that economic growth increases incomes, which increases the demand for a cleaner, more attractive environment (other things - especially prices - equal). One variant on this argument is that societies with higher incomes tend to have better ways of dealing with market failures in the environmental sphere (either because they are better at governance in general, which has helped them become richer, or because good governance is expensive). A corollary is that higher rates of environmental degradation in poorer societies do not necessarily imply that environmental goods are a luxury; apparently high income elasticities of demand for such goods may simply reflect the inability of people in poorer societies to express their preferences with respect to the environment. Direct estimates of income elasticities cast doubt on the assumption that environmental goods are in fact regarded as luxuries (Kriström and Riera, 1996). Another variant invokes a supply-side argument rather than a demand-side argument: richer societies tend to have a comparative advantage in products that are less environmentally harmful, perhaps because they are more intensive in the use of human capital and less in material inputs. Economists have framed the debate by hypothesising that these two opposing tendencies could give rise to a so-called environmental Kuznets curve (EKC) - an inverted U-shape relationship between per capita income and environmental quality, as illustrated in Figure 2(c). 
A variety of theoretical justifications for the EKC have been proposed. Stokey (1998) provides perhaps the simplest. She surmises that utility from consumption increases rapidly with diminishing returns, whilst the utility received from environmental quality, measured as the level of pollution, increases slowly with increasing returns, resulting in an inverted U-shape relationship as income increases over time. The main implication of the model is that the prospects for sustainable growth ultimately depend on whether a constant rate of return on capital is compatible with increasingly strict environmental regulation (Stokey, 1998). Jones and Manuelli (2001) develop a model where societies choose their preferred level of pollution by voting. Assuming that environmental quality is a luxury good, when society votes on the level of effluent charges they predict an inverted $U$, followed by a pollution increase, as in Figure 2(d). ${ }^{22}$ Andreoni and Levinson (2001) provide a very simple foundation for the EKC, relying solely on increasing returns to pollution abatement. ${ }^{23}$ This has the realistic implication that returns to abatement effort diminish as pollution is abated.
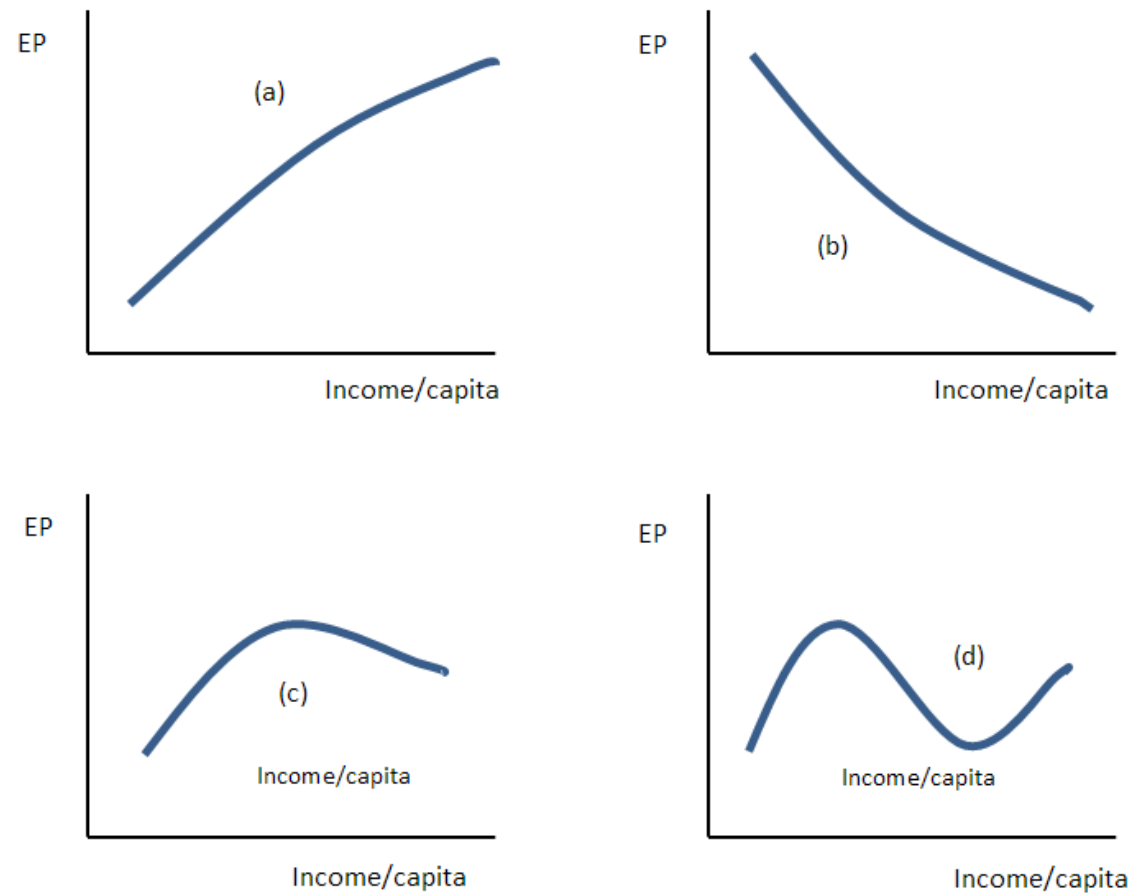

Figure 2: Relationships between environmental pressure (EP) and per capita income.

Despite a vast amount of empirical work done on the EKC hypothesis, evidence supporting the hypothesis is at best specific to local pollutants; there is no clear evidence that the EKC holds at the global and general level. Evidence supporting the EKC by Grossman and Krueger (1995), Cole et al. (1997), Shafik (1994) and Selden and Song (1994) shows estimated turning points at per capita incomes of between 1985 US\$3,280 to $\$ 14,700$ for a variety of local air and water pollutants. For global

\footnotetext{
${ }^{22}$ In contrast, when voting is on the dirtiest allowable technology, Jones and Manuelli (2001) find that pollution increases monotonically to a bounded maximum, as in Figure 2(a).

23 'Increasing returns' us used to imply that the more pollution there is before abatement begins, the less costly it is to abate each unit of pollution.
} 
pollutants such as $\mathrm{CO}_{2}$, turning points are modelled to be well above incomes currently achieved by any nation, potentially consistent with Figure 2(a) or 2(c). Furthermore, work by Shafik (1994) on faecal content and Grossman and Krueger (1995) on urban $\mathrm{SO}_{2}$ concentrations shows evidence of a cubic relationship, as in Figure 2(d), where pollution levels show a second turning point at higher incomes. Grossman and Krueger (1991) also find an 'N-shape' rather than an inverted-U shape for aggregate material inputs per unit output through time. Moreover, after a thorough review of the literature, Ekins (2000) concludes that the EKC is not unequivocally supported for any individual environmental indicator and is rejected for environmental quality as a whole. Stern (2004) suggests that developing countries are adopting developed-country behaviour with respect to some environmental issues, thus eroding any traditional EKC relationship. This conclusion is supported by Caviglia-Harris et al. (2009), whose analysis of EKC using Ecological Footprint measures also found no significant EKC relationship between development and growth. Stern (2004) also concludes, "The evidence ... shows that the statistical analysis on which the environmental Kuznets curve is based is not robust. There is little evidence for a common inverted U-shaped pathway that countries follow as their income rises." This echoes Copeland and Taylor (2004, p.8), who write, "Our review of both the theoretical and empirical work on the EKC leads us to be sceptical about the existence of a simple and predictable relationship between pollution and per capita income".

In addition to the lack of support in the empirical literature, there is confusion about the relevance of the EKC hypothesis to the 'limits to growth' debate. In one of the less confused statements, Ekins (2000, Chapter 7) states that accepting the EKC hypothesis "turns the 'limits to growth' argument on its head". Instead of the environment setting limits to growth, these conclusions suggest that growth is a requirement of environmental improvement. While less confused, this is nevertheless misleading in so far as it suggests that proof of the EKC would imply the possibility of unbounded growth. In principle, one can accept that economic growth improves environmental quality while also holding that environmental limits will nevertheless prevent unbounded growth.

Furthermore, there are three other reasons why the nexus between the EKC and the limits to growth debates is not as strong as might be thought. First, as noted above, the EKC appears to be most convincing if it is a microeconomic phenomenon, which is not necessarily applicable in the aggregate. Second, one theoretical basis for the EKC is the fact that pollution reductions are less costly when processes are less efficient to begin with. ${ }^{24}$ But, as production processes become more efficient and reach their thermodynamic limits, a lower bound of pollution per unit output will be attained. As such, proof of the EKC hypothesis would not necessarily imply that growth is unconstrained by environmental bounds. Once thermodynamic efficiency is achieved, unless some alternative use for the waste products is discovered, increases in material output will cause corresponding, unambiguous increases in pollution. Third, the independent variable employed in the EKC literature - per capita income- conflates income derived from a range of different sources, some of which are materials intensive and others 'material efficient' (Baptist and Hepburn, 2012). We discuss this further in Section 3. In sum, given these three reasons, the proof or otherwise of the

\footnotetext{
${ }^{24}$ See Andreoni and Levinson (2001).
} 
EKC will not decide the question of the environmental limitations on economic growth.

The next section looks in more detail at the feasibility of sustained growth in value. We ask in more detail what would be required to 'decouple' the economy from its material basis so that GDP growth can continue while increases in certain material throughputs (e.g. $\mathrm{CO}_{2}$ emissions) gradually decline to sustainable levels.

\section{Decoupling and the feasibility of sustained growth}

Changes in technology are one of the main factors in determining the development and long-run growth of an economy. For welfare to continue to rise with economic growth, future growth must damage the environment at a slower rate, and eventually it must actually preserve the some stock level of natural capital altogether. In other words, increases in economic output eventually must be 'decoupled' from increases in pressure on the environment. Is this feasible?

\subsection{Is zero economic growth the answer?}

Several scholars and commentators, including Jackson (2009), think that growth in economic activity itself is the fundamental problem, and that we must strive for 'prosperity without growth'. Jackson emphasizes the importance of distinguishing between 'relative' and 'absolute' decoupling of economic output and environmental pressure. Relative decoupling implies a reduction in the environmental pressure per unit of economic output. So-called 'absolute decoupling' is a reduction in environmental pressure. Thus, if economic growth is assumed to continue, relative decoupling is a necessary, but not sufficient, condition for absolute decoupling. Jackson (2009) argues that, in the long run, absolute decoupling is an essential condition for economic activity to remain within ecological limits.

There is clear evidence of relative decoupling in various forms. This is not surprising. Firms have incentives (if imperfect) to stimulate innovation and make improvements in efficiency to reduce input costs, including resource consumption and environmental damage (where this is priced). For example, global energy intensity is now 33\% lower than it was in 1970 in the OECD countries (IPCC, 2007). However, for absolute decoupling to occur, resource efficiencies must increase at least as fast as economic output increases.

Whilst there is frequent evidence of relative decoupling, evidence of absolute decoupling is less common. Absolute decoupling has been observed in some resources. For example, forest cover is increasing, rather than decreasing, in rich countries, flint is no longer needed in axes, saltpetre for gunpowder, or guano for fertilizer. However, in the context of climate change, there has been only relative, not absolute, decoupling of economic growth and greenhouse gas (GHG) emissions. The 'IPAT equation' of Ehrlich and Holden (1971) can be used to explore the relevant relationships. Let $I$ denote total 'impact', measured in tonnes of $\mathrm{CO}_{2} \mathrm{e}$, let $P$ denote global population, let $A$ denote affluence, measured by GDP per capita, and let $T$ 
denote 'technology' in the form of the $\mathrm{CO}_{2} \mathrm{e}$ emissions intensity of GDP. ${ }^{25}$ Then it is an accounting identity that:

$$
I=P A T
$$

and hence:

$$
\ln I=\ln P+\ln A+\ln T
$$

Differentiating all terms with respect to time gives the relationship between the growth rates of the variables:

$$
\frac{I}{I}=\frac{\dot{P}}{P}+\frac{A}{A}+\frac{\dot{T}}{T}
$$

Empirically, at the global level over the past 20 years, annual population growth, $P / P$, has been $1.3 \%$, annual GDP per capita growth, $\dot{A} / A$, has been $1.4 \%$ and emissions per unit of GDP, $T / T$, has been falling by $0.75 \%$ p.a. The identity indicates that $\mathrm{CO}_{2} \mathrm{e}$ emissions have been growing at $2 \%$ per annum:

$$
\frac{I}{I}=1.3 \%+1.4 \%-0.7 \%=2 \%
$$

Jackson (2009) employs this identity to argue as follows. First, while there has been relative decoupling $(\dot{T} / T<0)$ over the past 20 years, there is not yet any evidence of absolute decoupling $(I / I>0)$ between GHG emissions and economic output. Second, on the basis of the experience over the past 20 years, he concludes that absolute decoupling is not possible, because he dismisses the possibility of a structural shift in technological progress that would lower the emissions intensity of GDP to the degree required. He notes that in order for emissions to fall at the level to achieve the $2^{\circ} \mathrm{C}$ global temperature change target, this requires $I / I=-4.9 \%$. Allowing for an anticipated reduction in reduced annual population growth to $P / P=0.7 \%$, this annual emissions intensity to fall at the level $T / T=-7 \%$, an enormous challenge. Third, given this arithmetic, he (erroneously) concludes from this that the only solution is to target 'prosperity without growth.' That is, his solution is to reduce $A / A$ from $1.4 \%$ to $0 \%$. It is simple addition that the implication of the cessation of economic growth, with current rates of population growth and technological change, is that annual $\mathrm{CO}_{2}$ emissions growth would be:

$$
\frac{I}{I}=1.3 \%+0 \%-0.7 \%=0.6 \%
$$

The conclusion is that even halting economic growth does not produce absolute decoupling (as $(I / I>0)$, and it certainly does not deliver $I / I=-4.9 \%$, as required to restrain temperature increases to less than $2^{\circ} \mathrm{C}$. Achieving this, under Jackson's zero growth scenario, would still require a radical, structural shift in technology to

\footnotetext{
${ }^{25}$ An alternative measure is the Kaya identity (Kaya and Yokobori, 1997), which further splits $\mathrm{CO}_{2} \mathrm{e}$ intensity into (i) energy use per unit of GDP and (ii) $\mathrm{CO}_{2} \mathrm{e}$ emissions per unit of energy consumed.
} 
$T / T=-5.6 \%$, implying a dramatic reduction in the emissions intensity of GDP. Indeed, it is precisely this sort of structural shift that Jackson rules out to justify his 'no growth' world.

It is clear to a very large number of scholars and others that shifting $\dot{T} / T$ from $-0.7 \%$ to $-7 \%$ p.a. is an extreme challenge. However, reducing $T / T$ to $-5.6 \%$ while simultaneously $A / A$ is reduced to $0 \%$ is even more difficult economically (observe the relationship between affluence, $R \& D$ investment and the potential for a structural shift), and impossible politically, and is socially undesirable. The consequences of sharply slowing (let alone stopping) growth are observable in the West at present: high unemployment, increased levels of crime and mental illness, large-scale strikes and so on show the social damage wrought by an economic contraction.

Our point is that both paths involve Herculean challenges, and a 'no growth' world does not solve the problem of climate change or other environmental problems. Rather, for the sake of prosperity and indeed the likelihood of success, it is better to drive increases in technological progress, leading to reductions in intensity, to generate absolute decoupling along with stable growth. Instead of trying to work out how to stop growth at least cost, the significant and important question is how to stimulate a structural shift and a radical change in T. We need 'green growth', not 'no growth'.

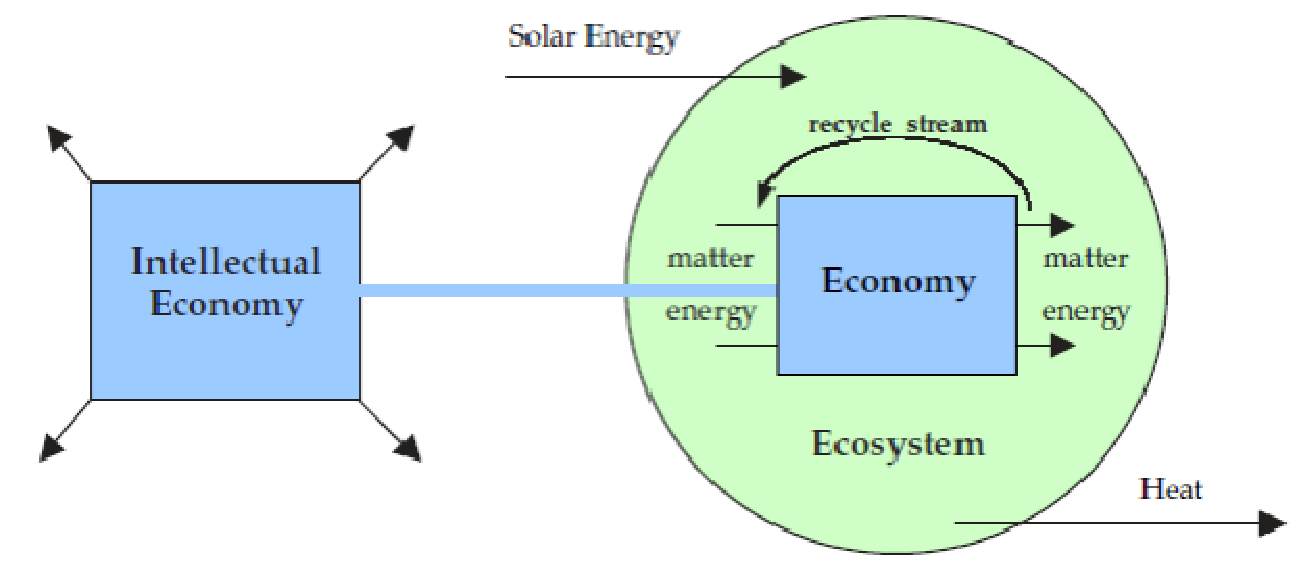

Figure 3: The material economy is bounded by the ecosystem; the intellectual economy is not

\subsection{A conceptual vision of (absolute) decoupling}

Consumption, properly defined, is broader than the enjoyments gained merely from the material world. This should not be a controversial statement. When people over the centuries have 'consumed' Rembrandt's Night Watch, the novels of Dickens, or Bach's Saint Matthew's Passion, many of them have felt awestruck at human capability, and have, in economic jargon, seen their utility increased (even if the impacts might more correctly be seen as being immeasurable). Critically, consumption of such non-material, or 'intellectual', goods - ideas, art, literature, 
psychological insight, music - is not bounded by the entropy law in the way that material processes must succumb to the laws of nature. As such, there is no physical limit to the progress of the 'intellectual' economy. And as many intellectual outputs are non-rival in consumption, the value of the intellectual economy can expand as access to it expands, without significant extra material input. More prosaically, many activities categorised as services rely only to a relatively small extent on material inputs - for example, the provision of a Facebook page. And some products usually regarded as the outputs of the manufacturing sector, such as CDs or computer memory chips, derive most of their value from their intellectual content.

Quah (1997, 1999) elaborates on some of the implications of what he calls the weightless economy for industrial organisation and economic development. He notes "...the increasing importance in national income of knowledge-products - computer software, new media, electronic databases and libraries, and Internet delivery of goods and services"(Quah, 1999). He uses the term knowledge-products to describe such products not because they are knowledge-intensive in production (although they often are), but because their physical properties resemble those of knowledge - infinite expansibility and irrelevance of physical distance. Weitzman (1996) argues that new ideas are generated by bringing different existing ideas together, implying that the set of potential ideas is limitless. John Stuart Mill (1848, p 129) asserted that while the material economy would attain a stationary state, our intellectual development could increase indefinitely:

\section{It is scarcely necessary to remark that a stationary condition of capital and population implies no stationary state of human improvement. There would be as much scope as ever for all kinds of mental culture, and moral and social progress; as much room for improving the Art of Living and much more likelihood of its being improved, when minds cease to be engrossed in the art of getting on.}

Figure 3 presents a simplistic relationship between the economy and the environment, in which the material economy is bounded by the ecosystem (i.e. physical throughput must eventually bump up against limits), while there is the potential for the unrestricted development of ideas in the intellectual economy. Like increases in material consumption, progress in the intellectual economy increases our well-being. In other words, the question to ask is not whether we can sustain limitless growth in material consumption - we cannot - but whether we will be able indefinitely to sustain increases in well-being. Seen through this lens, aspects of all three schools of thought, outlined above, are correct. Proponents of infinite economic growth would not claim that humans can circumvent the laws of thermodynamics, nor would they contend that unbounded increases to material output are possible with finite matter. Rather, the sensible claim is that technological progress can support infinite 'economic growth' - growth in value to humans - because the intellectual economy is unbounded, even if a stationary material economy is attained in the long run. ${ }^{26}$

The concept of an 'environmental drag' on growth can also be accounted for. In the long run, although the material economy is not growing, it is still producing material

\footnotetext{
${ }^{26}$ Quah (1999) points out that societies may fail to achieve such growth, citing as an example the decline of Chinese inventions and technological progress after the $14^{\text {th }}$ century.
} 
output at a constant rate. Constant material production implies non-zero pollution levels, which will exert a drag on utility growth. 'Economic growth' can therefore be sustained with zero material growth and increasing intellectual growth, allowing for a drag exerted by pollution. In short, all three schools of thought are able to be accounted for in the conceptual model represented in Figure 3.

In this manner, models with a steady state optimum, such as Stokey (1998), Michel and Rotillon (1995) and Withagen (1995) can be interpreted as evidence that a stationary material state will eventually be attained. The views expressed by Daly (1996) are consistent; he argues that there is a critical distinction between 'growth' (which he defines to be material growth) and 'development' (which essentially constitutes intellectual progress and improvements in well-being). In other words, once the material needs of the society have been satisfied, it is optimal for people to expend their efforts in the intellectual and artistic realms, along the lines envisaged by John Stuart Mill (1848, p129) and John Maynard Keynes (1930), the latter of whom suggested in his essay entitled 'Economic Possibilities for our Grandchildren' that:

a point may soon be reached, much sooner perhaps than we are all of us aware of, when those needs are satisfied in the sense that we prefer to devote our further energies to non-economic purposes.

\subsection{The evidence on decoupling}

Past evidence of structural shifts in various sectors may provide an insight into the general process of decoupling, and to map progress. Understanding the process by which technological change and structural transitions occur can assist by suggesting policies that might be put in place to increase the probability of an accelerated shift, in this case in the realm of clean technology. By definition, past evidence of the absence of absolute decoupling does not and cannot provide proof of the impossibility (or possibility) of any future structural shift to clean technology.

Historically, periods of technological change have been characterized by substantial reductions in cost and improvements in performance through learning; dynamic competition between technologies and the co-evolution of long-lived infrastructures and technological clusters due to 'network effects' (Grübler, Nakićenović and Victor, 1999). In computing, this process of technological change was so rapid that the number of components that could fit on an integrated circuit, economically, had doubled every year from the invention of the integrated circuit in 1958 until 1965 (Moore, 1965). Moore predicted that the trend would continue for at least another decade. In fact, the trend has continued for over half a century now with the number of transistors that can be placed inexpensively on an integrated circuit doubling every eighteen months. The question of interest is whether the coming decades might see something similar to Moore's law begin to apply to the energy industry and, if it does, whether we can expect growth to lead a structural shift, resulting in absolute decoupling.

To take one example of several energy technologies where innovation is accelerating, Moore's law might conceivably apply to the solar photovoltaics (PV) industry in future. The power that can be generated by PV for each dollar of cost has been doubling every seven years. This is nowhere near as rapid as the eighteen-month doubling time for computing power. The difference may be partly due to lower levels 
of R\&D expenditure on solar PV, the fact that energy is an undifferentiated good, and the stronger competitive pressure on computing firms, which must innovate or cease to exist (in contrast to many regulated energy utilities).

The solar PV industry has, however, had some recent changes that might signal an acceleration in these developments. Costs have fallen $30 \%$ over the past 18 months (2009-2011) with the emergence of large-scale production facilities in China. The recently increased scale of the industry might signal the start of existential competitive pressure on firms. Also, in recent years, there has been aggressive development of non-silicon-based PV materials (Wadia et al., 2009), driven by fluctuating silicon prices. The likelihood of a Moore's law in scale and cost will depend on various factors, including the judicious selection of photosynthetic materials that are in great abundance, and which are cheap. To take one example, for a given set of assumptions about material density and performance efficiency, it may be that iron sulphide $\left(\mathrm{FeS}_{2}\right)$ would produce 10,000 times more electricity than siliconbased PV (Wadia et al., 2009). Nanotechnology solar PV cells have the potential to utilize far less material, bringing about decreasing costs and faster production, and therefore a more rapid decline in costs.

Ultimately, absolute decoupling of GHG emissions from economic output, while apparently very challenging from the vantage point of 2012, may appear by 2050 to have been a relatively easy challenge. A structural shift that leads to renewable energy becoming significantly cheaper than fossil fuels would trigger such decoupling. Previous structural shifts are evident throughout history. For example, by the seventeenth century, the predominant energy source in England and Belgium was coal. As has been observed, this was due not to a shortage of wood, but to the cost of coal for heating becoming cheaper than that of wood (Fouquet, 2008). A structural shift in renewable technology costs is far from unimaginable if governments accelerate investment in $\mathrm{R} \& \mathrm{D}$ and deployment of such technologies. It is too early to rule out absolute decoupling.

\subsection{Rebound effects and the impact on economic output}

A structural shift towards low-cost renewable energy would have various effects on the economy. First, it would reduce GHG emissions and, if big enough, help to solve the challenge of climate change. Second, lower energy prices would increase energy consumption, increasing economic output (Ayres and Warr, 2005) potentially increasing emissions in other sectors as they expand. The prospect of displacement by renewable energy providers could lead owners of fossil fuel stocks to accelerate their use, pushing down energy prices and encouraging emissions in the near term (Sinn, 2008). These are forms of the 'rebound effect', in which actions taken to increase efficiency reduce the unit cost of use and hence lead to increased demand. ${ }^{27}$

More generally, Baptist and Hepburn (2012) provide evidence that begins to suggest that treading lightly on the planet need not reduce economic growth in value terms. They analyse a panel-data set of 473 manufacturing sectors in the United States over

\footnotetext{
27 See Sorrell (2007) and Sorrell and Dimitopoulos (2007) for a review of rebound effects. These effects can be direct (due to income and substitution effects) and indirect (resulting from embodied energy and secondary effects) (Fouquet, and Pearson, 2011).
} 
48 years, and find that sectors with lower material intensity had higher total factor productivity, as did those with higher labour intensity. In other words, using less 'stuff' and more 'human intelligence' increased overall productivity and economic output. Rebound effects may concern environmentalists, but increases in output imply increases in welfare and should be welcomed if environmental consequences are properly priced.

\section{Conclusions and policy implications}

Intense debate about the environmental limits to growth has been taking place over the past few decades. Three competing schools of thought are identified here: that growth is limitless, that environmental conditions will place a 'drag' on growth, and that economic growth cannot continue indefinitely. We propose an approach which incorporates the essence of the three competing schools of thought. Our conceptual model shows an eventual stationary state in the material economy (which may still be decades or many centuries into the future), with unbounded growth in the intellectual economy, notwithstanding a genuine drag on growth in welfare from environmental constraints.

We engage directly with those who advance a 'zero growth' world as being necessary to live within environmental limits, and see economic growth as a problem. We demur. We have argued that stopping economic growth (which is measured in terms of value) is neither necessary nor desirable. Indeed, as far as meeting environmental challenges is concerned, it would be counterproductive; recessions have slowed and in some cases derailed efforts to adopt cleaner modes of production. Rather, large leaps in clean technology, triggering a structural shift in the way we produce and consume energy, are required. This is a 'green growth' rather than a 'no growth' world. The continuation of growth in value to humans is consistent with us living within the material constraints imposed by a finite (if very large) planet, provided that we continue to expand the intellectual economy through innovation, technology development, an increased focus on services and, more fundamentally, the art of living.

The policy implications from this chapter are unsurprising. The large scale of the subsidies spent annually on increasing the size of the material economy should be reduced. As Baptist and Hepburn (2012) note, very approximately US \$1 trillion is spent on directly subsidizing the consumption of resources, which includes approximately $\$ 400$ billion on energy, around \$200-300 billion of equivalent support on agriculture, and approximately US \$200-300 billion on water. Perhaps another US $\$ 1$ trillion, very approximately, takes the form of subsidy for the use of the atmosphere as a sink for greenhouse gas emissions. Other subsidies - in the form of incorrect environmental prices - create annual damage in the trillions every year.

In contrast, the scale of the intellectual economy should be increased. Public authorities need to tackle the well-known market failures that tend to lead to insufficient pure research and R\&D spending by the private sector, and also consider whether they can help firms reap increasing returns to scale, for example, by supporting new networks in their early development. Shifting the tax base towards materials and resources, and away from labour and other intellectual activity, might also contribute to building the intellectual economy. It might also increase economic 
output, given that labour is the factor input that correlates most closely with higher total factor productivity (Baptist and Hepburn, 2012). And it would increase the odds that the rate of reduction in cost of clean technologies would increase, so that solutions are found for our environmental challenges.

\section{References}

Adkins, L., R. Garbaccio, M. Ho, R. Moore and R. Morgenstern (2010), 'The Impact on U.S. Industries of Carbon Prices with Output-Based Rebates over Multiple Time Frames', RFF Discussion Paper, 10-47.

Aghion, P. and P. Howitt (1992), 'A model of growth through creative destruction', Econometrica, 60(2), 323-351.

Aghion, Phillipe. and Peter Howitt (1998), Endogeneous Growth Theory, Cambridge MA, US: MIT Press.

Andreoni, J. and A. Levinson (2001), 'The simple analytics of the environmental Kuznets curve', Journal of Public Economics, 80(2), 269-286.

Ayres, R. and B. Warr (2005), 'Accounting for growth: the role of physical work', Structural Change and Economic Dynamics, 16, 181-209.

Baptist, S. and C. Hepburn (2012), 'Material efficiency, productivity and economic growth', Philosophical Transactions of the Royal Society A (forthcoming).

W. Beckerman (1992), 'Economic Growth and the Environment: Whose Growth? Whose Environment?', World Development, 20(4), 481-496

Bovenberg, A. and S. Smulders (1995), 'Environmental quality and pollution augmenting technological change in a two-sector endogenous growth model', Journal of Public Economics, 57(3), 369-391.

Bruvoll, A., S. Glomsrod, and H. Vennemo (1999), 'Environmental drag: evidence from Norway', Ecological Economics, 30(2), 235-249.

M. Byrne (1997), 'Is growth a dirty word? Pollution, abatement and endogenous growth', Journal of Development Economics, 54(2), 261-284.

Caviglia-Harris. J., D. Chambers and J. Kahn (2009), 'Taking the 'U' out of Kuznets: A comprehensive analysis of the EKC and environmental limits', Ecological Economics, 68(4), 1149-1159.

C. Clark (1997), 'Renewable resources and economic growth', Ecological Economics, 22(3), 275- 276.

Cole, M., A. Rayner, and J. Bates (1997), 'The environmental Kuznets curve: an empirical analysis', Environment and Development Economics, 2(4), 401-416.

Collier, P. (2007), "The Bottom Billion: Why the Poorest Countries are Failing and What Can Be Done About It", Oxford University Press, Oxford.

Campbell, C.J and J.H. Laherrère (1998), "The end of cheap oil", Scientific American, March, 78-83.

Copeland, B. and S. Taylor, (2004), 'Trade, Growth, and the Environment', Journal of Economic Literature, 42(1), 7-71. 
H. Daly (1992), 'Is the entropy law relevant to the economics of natural resource scarcity? - Yes, of course it is!' Journal of Environmental Economics and Management, 23(1), 91-95.

Herman Daly (1996), Beyond Growth: The economics of sustainable development, Sussex, UK: Beacon Press.

H. Daly (1997), 'Georgescu-Roegen versus Solow/Stiglitz', Ecological Economics, 22(3),261- 266.

Dobbs R, J. Oppenheim and F. Thompson (2011), 'A new era for commodities', McKinsey Quarterly, November, 1-3.

Ehrlich, P. and J. Holden (1971), 'Impact of population growth', Science, 171(3977), 1212-1217.

Paul Ekins (2000), Economic Growth and Environmental Sustainability, London, UK: Routledge.

Roger Fouquet (2008), Heat Power and Light: Revolutions in Energy Services, Cheltenham and Northampton, MA, USA: Edward Elgar.

Fouquet, R. and P. Pearson (2011), 'The Long Run Demand for Lighting: Elasticities and Rebound Effects in Different Phases of Economic Development', BC3 Working Paper Series, 2011-06, 1-22.

Benjamin Friedman (2005), The Moral Consequences of Economic Growth, New York:, USA: Alfred A. Knopf.

Nicholas Georgescu-Roegen (1966), Analytical Economics, Cambridge MA, USA: Harvard University Press.

Nicholas Georgescu-Roegen (1971), The Entropy Law and the Economic Process, Cambridge MA, USA: Harvard University Press.

N. Georgescu-Roegan (1975), 'Energy and economic myths', Southern Economic Journal, 41(3), 347-381.

A. Grimaud (1999), 'Pollution permits and sustainable growth in a Schumpeterian model', Journal of Environmental Economics and Management, 38(3), 249266.

Grossman, G. and E. Helpman (1991), 'Quality ladders in the theory of growth', Review of Economic Studies, 58(1), 43-61.

Grossman, G. and E. Helpman (1994), 'Endogenous innovation in the theory of growth', Journal of Economic Perspectives, 8(1), 23-44.

Grossman, G. and A. Krueger (1991), 'Environmental impacts of a North American Free Trade Agreement', National Bureau of Economic Research Working Paper 3914.

Grossman, G and A. Krueger (1995), 'Economic Growth and the Environment', Quarterly Journal of Economics, 110(2), 353-377.

Grübler, A., N.Nakićenović, and D.Victor (1999), 'Dynamics of energy technologies and global change', Energy Policy, 27(5), 247-280.

Heal, G. (2011), 'Sustainability and its measurement', NBER Working Paper No. 17008, May. 
Helm, D. (2011), 'Peak-oil and energy policy - a critique,' Oxford Review of Economic Policy, 27(1), 668-91.

John Hicks (1983), 'Classics and Moderns, Collected Essays on Economic Theory', Volume III, Cambridge MA, USA: Harvard University Press.

H. Hotelling (1931), 'The Economics of Exhaustible Resources', Journal of Political Economy, 39(2), 137-175.

IPCC (1990), Climate Change: The IPCC Scientific Assessment, Cambridge, UK and New York, USA: Cambridge University Press.

IPCC (2007), Contribution of Working Groups I, II and III to the Fourth Assessment Report of the Intergovernmental Panel on Climate Change, Cambridge, UK and New York, USA: Cambridge University Press

Tim Jackson (2009), 'Prosperity without growth: economics for a finite planet', London, UK: Earthscan

W. Jevons (1865), The Coal Question: an Inquiry Concerning the Progress of the Nation and the Probably Exhaustion of Our Coal Mines, New York, USA: Augustus M Kelley.

D. Johnson (2000), 'Population, Food, and Knowledge', American Economic Review, 90(1) $1-14$.

Jones, L. and R. Manuelli (2001), 'Endogeneous policy choice: the case of pollution and growth', Review of Economic Dynamics, 4(2), 369-405.

R. Kanbur (2001), 'Economic Policy, Distribution and Poverty: The Nature of Disagreements', World Development, 29(6), 1083-1094

Yoichi Kaya and Keiichi Yokobori, (1997), Environment, energy and economy: Strategies for sustainability, New York, USA: United Nation University Press.

John Maynard Keynes (1930), Essays in Persuasion, New York, USA: W W Norton \& Co.

H. Kharas (2010), 'The emerging middle class in developing countries', $O E C D$ Development Centre Working Paper, 285( January), 1-61.

King, D. and J. Murray (2012), 'A phase shift in oil', Nature, 481, 433-435.

Kriström, B. and P. Riera (1996), 'Is the Income Elasticity of Environmental Improvements Less Than One?', Environmental and Resource Economics 7, 45-55.

S. Kuznets (1955), 'Economic Growth and Income Inequality', American Economic Review, 45(1), 1-28.

Bjorn Lomborg (2001), The Skeptical Environmentalist: Measuring the Real State of the World, New York, USA: Cambridge University Press.

Thomas Malthus (1798), An Essay on the Principle of Population, London, UK: W. Pickering (1986).

Meadows, Dennis, Donella Meadows and Jorgen Randers (1992), Beyond the limits: global collapse or a sustainable future, London, UK: Earthscan Publications. 
Dennis Meadows, Donella Meadows, Jorgen Randers and William Behrens III (1972), The Limits to Growth: a report for the Club of Rome's Project on the Predicament of Mankind, New York, USA: Universal Books.

Michel, P. and G. Rotillon (1995), 'Disutility of Pollution and Endogenous Growth', Environmental and Resource Economics, 6(3), 279-300.

John Stuart Mill (1848), Principles of Political Economy with some of their Applications to Social Philosophy, Oxford, UK: Oxford University Press.

Ezra Mishan (1967), The costs of economic growth, New York, USA: Praeger.

Moore, G. (1965), 'Cramming more components onto integrated circuits', Electronics, 38(8), 114-117

Eric Neumayer (2003), Weak versus Strong Sustainability: Exploring the Limits of Two Opposing Paradigms, Northampton, MA, USA: Edward Elgar.

W. Nordhaus (1973), 'World Dynamics: Measurement without Data', Economic Journal, 83(332), 1156-83.

W. Nordhaus (1992), 'Lethal Model 2: The Limits to Growth Revisited', Brookings Papers on Economic Activity, 23(2), 1-60.

J. Opschoor (1997), 'The hope, faith and love of neoclassical environmental economics', Ecological Economics, 22(3), 281-283.

Quah, D. (1997), 'Increasingly weightless economies', Bank of England Quarterly Bulletin, February, 49-56.

Quah, D. (1999), 'The weightless economy in economic development', Centre for Economic Performance Discussion Paper No. 417, London School of Economics and Political Science, March.

Rockström, J., Steffen, W., Noone, K., Persson, A., Chapin, F. S., Lambin, E. F., Lenton, T. M., Scheffer, M., Folke, C. et al. (2009) A safe operating space for humanity. Nature, 461(24), 472-475.

David Romer (2006), Advanced Macroeconomics, New York, USA: McGraw Hill.

P. Romer (1986), 'Increasing Returns and long-run growth' Journal of Political Economy, 94(5), 1002- 1037.

P. Romer (1990) 'Endogeneous technological change', Journal of Political Economy, 98(5), 71-102.

P. Romer (1994), 'The origins of endogenous growth', Journal of Economic Perspectives, 8(1),3-22.

Ernst Schumacher (1973), Small is Beautiful: a study of economics as if people mattered, London, UK: Blond and Briggs Ltd.

Selden, T. and D. Song (1994), 'Environmental Quality and Development: Is there a Kuznets Curve for Air Pollution Emissions,' Journal of Environmental Economics and Management, 27(2), 147-162.

N. Shafik (1994): 'Economic Development and Environmental Quality: An econometric analysis', Oxford Economic Papers, 46(0), 757-773.

J. Simon (1980), 'Resources, Population, Environment: An Oversupply of False Bad News', Science, 208(4451), 1431-1437. 
Julian Simon (1981): The Ultimate Resource, Oxford, UK: Robertson.

H. Sinn (2008), 'Public policies against global warming: A supply side approach', International Tax and Public Finance, 15, 360-394.

Adam Smith (1776), An Inquiry into the Nature and Causes of the Wealth of Nations, reprinted by Penguin Classics (1986), London.

F. Sollner (1997), 'A re-examination of the role of thermodynamics for environmental economics', Ecological Economics, 22(3), 175-201.

R. Solow (1956), 'A Contribution to the Theory of Economic Growth', Quarterly Journal of Economics, 70(1), 65-94.

R. Solow 1994), 'Perspectives on growth theory', Journal of Economic Perspectives, 8(1), 45-54.

R. Solow (1997), 'Georgescu-Roegen versus Solow/Stiglitz', Ecological Economics, 22(3),267- 268.

Steven Sorrell (2007), The Rebound Effect: An Assessment of the Evidence for Economy-Wide Energy Savings from Improved Energy Efficiency, London, UK: UK Energy Research Centre.

Sorrell, S., and J. Dimitropoulos (2007), 'The rebound effect: microeconomic definitions, limitations and extensions', Ecological Economics, 65(3), 636649.

Sorrell, S., R. Miller, R. Bentley, R. and J. Speirs (2010), 'Oil futures: A comparison of global supply forecasts' Energy Policy, 38(9), 4990-5003.

D. Stern (2004), 'The rise and fall of the Environmental Kuznets Curve', World Development 32(8), 1419-1439.

Nicholas Stern (2006), Review on the Economics of Climate Change, London, UK: H.M. Treasury.

J. Stiglitz (1974), 'Growth with exhaustible natural resources: efficient and optimal growth paths', Review of Economic Studies, 41(1), 123-137.

J. Stiglitz (1997), 'Georgescu-Roegen versus Solow/Stiglitz', Ecological Economics, 22(3), 269-270.

N. Stokey (1998), 'Are there limits to growth?', International Economic Review, 39(1), 1-31.

Tinbergen, Jan and Roefie Hueting (1992), 'GNP and Market Prices' in Robert Goodland, Herman Daly and Salah El Serafy (eds.) Population, Technology and Lifestyle: the Transition to Sustainability, Washington DC, USA: Island Press, pp. 52-62.

K. Townsend (1992), 'Is the entropy law relevant to the economics of natural resource scarcity? Comment', Journal of Environmental Economics and Management, 23(1), 96-100.

G. Turner (2008), 'A comparison to the limits of growth with thirty years or reality', Socio-Economics and Environment in Discussion CSIRO working paper series, 1-49. 
Wadia, A., P. Alivisatos and D. Kammen (2009), 'Materials Availability Expands the Opportunity for Large-Scale Photovoltaics Deployment', Environmental Science \& Technology, 43(6), 2072-2077.

M. Weitzman (1994), 'On the "Environmental" Discount Rate', Journal of Environmental Economics and Management, 26(2), 200-209.

M. Weitzman (1996), 'Hybridizing Growth Theory', American Economic Review, 86(2), 207-212.

C. Withagen (1995), 'Pollution, Abatement and Balanced Growth', Environmental and Resource Economics, 5(1), 1-8.

World Bank (2006): 'Where is the wealth of nations? Measuring capital for the $21^{\text {st }}$ century', World Bank, Washington D.C.

World Bank (2011): 'The little green data book', World Bank, Washington D.C.

Allyn A. Young (1928), 'Increasing returns to scale and economic progress', Economic Journal, 38, 527-42.

J. Young (1991), 'Is the entropy law relevant to the economics of natural resource scarcity?', Journal of Environmental Economics and Management, 21(2), 169-179. 